\title{
POSITIVE AND NEGATIVE ROLE OF NEGATIVE IONS IN COSMIC EXPLORATION
}

\section{Leonid I. Gretchikhin}

Belarusian State Academy of Communications, Minsk, Republic of Belarus, e-mail: gretchihin@yandex.ru,

ORCID iD: 10 https://orcid.org/0000-0002-5358-9037

DOI: 10.5937/vojtehg69-32109; https://doi.org/10.5937/vojtehg69-32109

FIELD: Physical mechanics, Aeronautics

ARTICLE TYPE: Original scientific paper

\begin{abstract}
:
Introduction/purpose: At altitudes of 80 to $40 \mathrm{~km}$, while the spacecraft made of duralumin without a thermal-protective coating was descending from the flight orbit at the first and second cosmic velocities, data were obtained on the increase in density, pressure, and temperature behind the shock front, as well as on the backout of the shock wave from the surface of the descending spacecraft.

Methods: Calculations were made of the energy fluxes on the surface of the spacecraft for every $10 \mathrm{~km}$, for convective and radiative heat transfer, as well as for the impact of electrons produced due to ionization of negative ions.

Results: At the first cosmic velocity, the greatest energy flux is realized under the influence of an electron flux, and at the second cosmic velocity, radiative heat transfer occurs. In the shock-compressed gas at all the considered altitudes, pressure increases instantly to a value of $109 \div 1011$ $\mathrm{Pa}$, which leads to a sequential explosion with increasing power resulting in shock waves in the surrounding atmosphere and compression waves in the entire aircraft structure. The last most powerful explosion occurs at an altitude of approx. $40 \mathrm{~km}$.

Conclusion: The descending aircraft is destroyed into separate small parts to the size of small dust particles.
\end{abstract}

Key words: negative ions, spacecraft, charging, convective heat transfer, radiative heat transfer, ionization phenomenon, shock waves, explosion.

\section{Introduction}

During flights of rockets and spacecraft in near and far space, as well as in the Earth's atmosphere, many new discoveries were made due 
to the interaction of aircraft with the environment. Let us list some of them:

1. When rockets fly at an altitude of $91-131 \mathrm{~km}$, only negative ions of atoms and molecules, both of the surrounding space and of various particles adsorbed on the rocket surface, are present in the boundary layer near the rocket surface (Johnson \& Keppner, 1956).

2. At high altitudes above the Karman line, a powerful charging of rockets and spacecraft occurs (Gretchikhin, 2018a).

3. During the reentry, the heat-protective coating burns at the first and the second cosmic velocities (Gretchikhin, 2018c).

4. There is a loss of radio communication with descending Earth satellites aircraft at altitudes of $80-20 \mathrm{~km}$ (Gretchikhin, 2016, and Gretchikhin, 1986).

5. In the free-molecular and transient flow regimes, the "Gretchikhin's effect" occurs (Gretchikhin, 2018a), (Gretchikhin, 2018c), (Gretchikhin, 2016), (Gretchikhin, 1986) and (Gretchikhin, 2003).

6 . When charged bodies fly in the process of interaction with a physical vacuum, friction occurs (Gretchikhin, 2018b), which prevents flights in deep vacuum.

7. During aircraft reentry with a second or higher cosmic velocity, a cascade of explosions of the boundary layer occurs (the Chelyabinsk meteor).

Some of these problems are solved and practically used, but most of them require in depth studies or creation of new theories, identification of new properties and making new discoveries. Let us take a closer look at the level at which a particular problem has been solved and outline the ways to improve them.

\section{Negative ions on the surface of the condensed matter}

The condensed matter in the form of a solid body consists of clusters. Clusters are formed by diatomic or triatomic molecules. In a solid, the interaction of clusters determines a different crystal structure with its distribution of atoms within the crystal. Between the clusters, a free space is formed, in which the initial particles of matter, which perform translational movement between the clusters, are located. The density of particle-particle packing in the cluster corresponds to the crystal packing density $(0.68-0.74)$. The packing density of free matter particles in the intercluster volume is $0.44-0.47$ (Elanskij, 1991). This is 
an experimental fact obtained using the molecular dynamics method together with the X-ray diffraction analysis.

In the formation of cluster structures, the valence electrons of molecules and atoms are generalized and create a cloud of free electrons. Previously, it was believed that the electrons in such a cloud follow the Fermi-Dirac distribution by energies. This is a rather rough representation. Experimentally, the distribution of free electrons by energies for a number of metals was obtained using the X-ray diffraction analysis. For example, Figure 1 shows such a distribution for an aluminum crystal, obtained from the K- and L-bands of characteristic Xray radiation. The theory of this phenomenon is developed and presented in works (Gretchikhin, 2004) and (Gretchikhin, 2008). The calculation results are shown in Fig. 1 for aluminum and in Fig. 2 for chromium.

$\varepsilon, \mathrm{eV}$

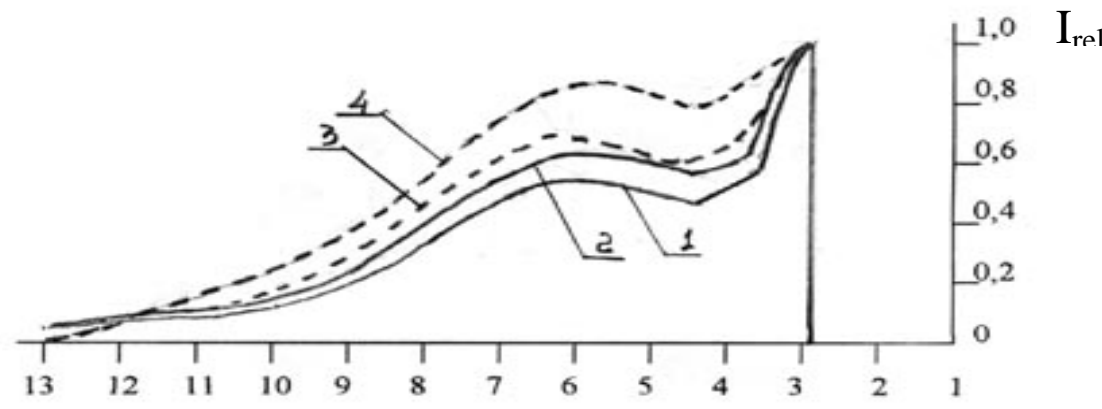

Figure 1 - Distribution of the electron density of valence electrons by energies for aluminum:

1 - theoretical calculation;

2 - theoretical calculation taking into account the U-shaped hardware broadening with an energy of $0.05 \mathrm{eV}$;

3 - experimental distribution from the L-band and 4 - from the K-band

Рис. 1 - Распределение электронной плотности валентных электронов по энергиям для алюминия:

1 - теоретический расчет;

2 - теоретический расчет с учетом П-образного аппаратного уширения с энергией 0,05 эВ;

3 - экспериментальное распределение из $L$ - полосы и 4 - из $K$-полосы

Слика 1 - Расподела електронске густине валентних електрона по енергијама за алуминијум: 1 - теоријски прорачун;

2 - теоријски прорачун који узима у обзир проширивање хардвера П-облика енергијом од $0,05 \mathrm{eV}$;

3 - експериментална расподела из зоне Л и 4 - из зоне $К$ 


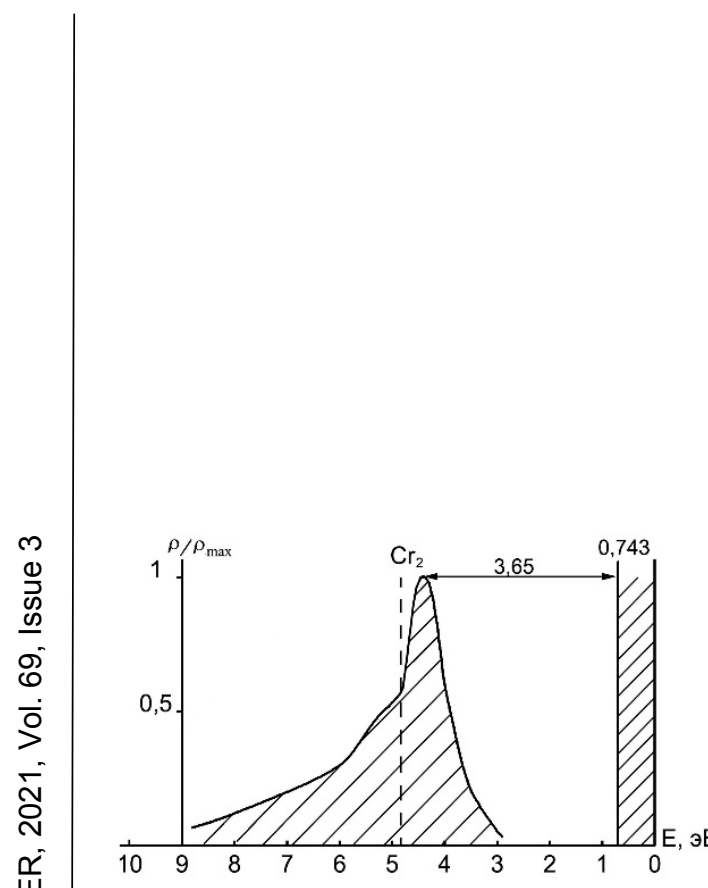

a)

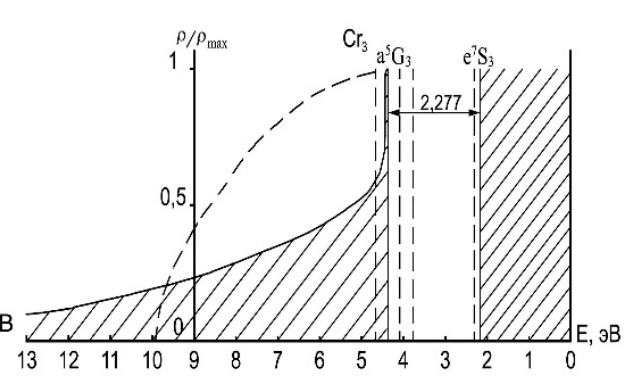

b)

Figure 2 -Distribution of the electron density of valence electrons by energies for chromium:

a) - clusters of diatomic molecules;

b) - clusters of triatomic molecules (the dotted line shows the distribution obtained using the band theory of metals)

Puc. 2 - Распределение электронной плотности валентных электронов по энергиям для хрома:

а) - кластеры из двухатомных молекул;

б) - кластеры из трехатомных молекул (пунктиром показано распределение, полученное с применением зонной теории металлов).

Слика 2 - Расподела електронске густине валентних електрона по енергијама за хром:

а) кластери двоатомских молекула;

б) кластери троатомских молекула (испрекидана линија показује расподелу добијену коришћењем теорије зона метала)

The electron density distribution varies depending on the type of cluster structures. This is clearly seen for chromium when clusters are formed by diatomic or triatomic molecules (Fig. 2). As a result of this phenomenon, a double electric layer is formed above the crystal surface. If the atoms of a crystal have an affinity for an electron, then, on the surface, they capture electrons from the double layer and remain in the form of negative ions. This fact was experimentally established and described in works (Gretchikhin, 2019) and (Shmermbekk et al, 2020). When such a crystal is placed in a vacuum, then due to thermal emission, free negative ions will appear on the surface of the crystal, which was discovered when the first rockets were launched into space (Johnson \& Keppner, 1956).

Under the influence of the incoming flux of neutral atoms and molecules of the environment, negative ions leave the surface of the solid body, and a double electric layer is created with the laying of a positive potential on a moving object in space. There is a spacecraft charging phenomenon. 


\section{Spacecraft charging in space}

At high altitudes, artificial Earth satellites (AES) fly in the freemolecular flow regime. The atoms and molecules of the environment bombard the surface of the aircraft. At high altitudes, oxygen atoms are present in a fairly large amount in the Earth's atmosphere. Due to physical adhesion, oxygen atoms surround the surface of the aircraft and create an oxygen film. Under the action of the incoming flux, the atoms of the incoming flux are exchanged with oxygen atoms, which leave the surface of the aircraft in the form of negative ions. As a result, the aircraft surface is positively charged. The charging theory was developed and it was found that the induced potential on the surface of the aircraft flying at altitudes above $1.000 \mathrm{~km}$ can reach approx. $1.5 \mathrm{kV}$. This potential disables all the electronics of the artificial Earth satellite through the common wire. During the first flights of the AES, this phenomenon was observed. It was necessary to put electrostatic sensors on the satellites and compensate for the satellite potential. Now this is all in the past, when, in the initial period of space exploration, it was not clear why satellites fail at high altitudes.

\section{Burning of heat-protective coating at the first and second cosmic velocities}

With the development of rocket technology, the space development began. The aircraft return from space takes place at the first cosmic velocity of approx. $7.5 \mathrm{~km} / \mathrm{s}$, and at the second cosmic velocity, it is approx. $11.2 \mathrm{~km} / \mathrm{s}$. At such velocities, powerful shock waves occur. The air is heated to high temperatures behind the shock wave. Various heatbarrier materials were used to protect descending spacecraft from the effects of emerging heat fluxes. For the first cosmic velocity, pyrolytic graphite with a thickness of up to $5 \mathrm{~cm}$ was used in the front hemisphere. This thickness was sufficient, since the thermal-protective coating of no more than $3 \mathrm{~cm}$ in size burned out.

During the spacecraft reentering at the second cosmic velocity, the heat-protective coating should be destroyed more intensively. The problem appeared: how can descending spacecraft be safely retrieved under such conditions? The temperature is very high in the emerging shock wave. Intense convective and radiative heat transfer occurs. Without taking into account the effects of negative ions, the theoretical calculation has allowed to establish that the thickness of burn-out of the 
thermal-protective coating can be approx. $2 \mathrm{~m}$. This result was shocking. Then the effects of negative ions had to be taken into account.

lonization of negative ions produces an intense flux of electrons to the surface of the thermal-protective coating, and in combination with the radiative and convective heat flux forms such a net energy flux that an explosion of the skin layer occurs. At this moment, heat stops coming to the spacecraft surface. The theory of such a phenomenon was developed and the calculations performed showed that the heatprotective coating at the second cosmic velocity should burn less than at the first cosmic velocity. After a circumlunar flight followed by the descent of the spacecraft at the second cosmic velocity, the thickness of the burned-out thermal-protective coating turned out to be approx. $2 \mathrm{~cm}$, i.e. less than at the first cosmic velocity with burn-out thickness of approx. $3 \mathrm{~cm}$. The combustion of the heat-protective material at the second cosmic velocity does not occur continuously, but in separate explosive pulses, and they shield the heat flux to the surface of the spacecraft.

\section{Loss of radio communication with the descending spacecraft}

The first launchings of geophysical rockets of the R-1, R-2, and R-5 type in the USSR allowed establishing that the loss of the radio communication occurs at the most important section of the rocket descent from flight altitudes from $80 \mathrm{~km}$ to $20 \mathrm{~km}$. From 1959, preparations for a human flight into space began. However, the main obstacle to the implementation of such a flight was the lack of reliable radio communication in a particularly dangerous area of the flight, where powerful shock waves occur, and radio communication is lost. Theoretical calculations of the plasma parameters under the influence of aerodynamic heat fluxes showed that communication in the meter range of radio waves should not be disrupted. In the event of a breakdown of communication flight segment when entering dense layers of the atmosphere, where powerful shock waves are formed, a person cannot be launched into space. Burning of the heat-protective coating consisting of pyrolytic graphite began to be studied.

When the satellite descends at the active part of the flight, the air behind the shock wave heats up to a temperature of over $1.000 \mathrm{~K}$ with a maximum at the first cosmic velocity of up to $10.000 \mathrm{~K}$, and at the second one - up to $15.000 \mathrm{~K}$. At such high temperatures, the heat-protective coating in the form of pyrolytic graphite is intensively destroyed. The phenomenon of ablation occurs. The destruction products of duralumin 
contain triatomic molecules, for which the electron affinity is approx. $1.785 \mathrm{eV}$. In case of graphite destruction, the emission occurs mainly of nitrogen dioxide and triatomic molecules, which have an electron affinity of 2.42 and $2.5 \mathrm{eV}$, respectively (Babichev et al, 1991), and, therefore, mainly leave the satellite surface in the form of negative ions. As a result, a double electric layer appears at the surface of the satellite, within which plasma with a high concentration of charged particles corresponding to an arc discharge is created. The calculation of the charged particles concentration for the descending spacecraft in the form of a ball with a radius of $1 \mathrm{~m}$ is shown in Fig. 3 (Gretchikhin, 2016). If radio communication is carried out in the meter or decimeter wavelength range, then, starting from an altitude of $80 \mathrm{~km}$, it completely stops. To ensure that radio communication is not disrupted, there are two possibilities: either to introduce a substance with a low ionization energy (alkali metals) into the double electric layer, which will sharply reduce the plasma temperature and stop the ionization of negative ions, or to impose a magnetic field on the plasma of the double layer. The first possibility is simpler and was therefore applied, but without much justification.

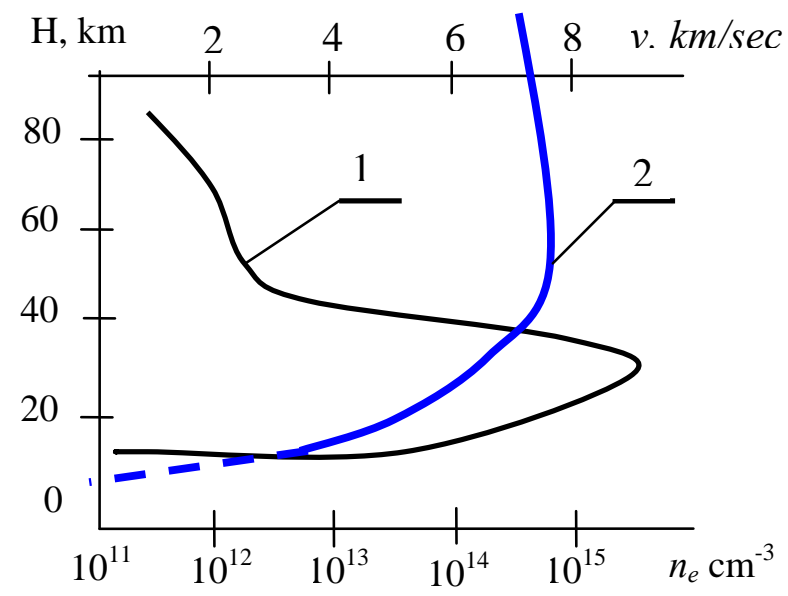

Figure 3 - Electron concentration of the double electric layer (1) and the flight velocity (2), depending on the altitude of the satellite's descent at the first cosmic velocity

Puс. 3 - Концентрация электронов двойного электрического слоя (1) и скорость полета (2) в зависимости от высоты снижения спутника при первой космической скорости

Слика 3 - Концентрација електрона двоструког електричног слоја (1) и брзина лета (2) у зависности од надморске висине спуштања сателита првом космичком брзином 
When an artificial Earth satellite reenters at an altitude of $50 \mathrm{~km}$, the flight velocity reaches approx. $7.5 \mathrm{~km} / \mathrm{s}$. Radio communication with the satellite is carried out at the frequency $f$ of approx. $640 \mathrm{MHz}$, for which the critical concentration of charged particles is $5.076 \cdot 10^{15} \mathrm{~m}^{-3}$.

In order for the radio signal to pass completely through the plasma, the concentration of charged particles in the double electric layer must be by an order lower, i.e. $5.076 \cdot 10^{14} \mathrm{~m}^{-3}$. In reality, the concentration of charged particles in the double electric layer at an altitude of $50 \mathrm{~km}$ is $n_{e} \approx 2 \cdot 10^{17} \mathrm{~m}^{-3}$ at a plasma temperature of $4,000-3,000 \mathrm{~K}$. The plasma frequency is equal to $f_{0} \cong 4 \cdot 10^{9} \mathrm{~Hz}$. Therefore, the frequency of $6.4 \cdot 10^{8} \mathrm{~Hz}$ from the plasma with a concentration of $n_{e} \approx 2 \cdot 10^{17} \mathrm{~m}^{-3}$ will be completely reflected. For radio communication, it is necessary to clear the plasma, which was practically implemented by introducing a liquid crystal coolant into the combustion zone.

The introduction of a liquid crystal coolant into the front hemisphere of the descending AES aircraft is schematically shown in Fig. 4. In case of continuous flow in the front hemisphere of the AES 1 moving at supersonic speed 4, a shock wave 2 occurs. The normal shock has the form of a circle with a diameter equal to the size of the descending spacecraft. The shock wave backout is approx. $17 \div 25 \mathrm{~cm}$. In the process of injection of a liquid metal coolant, the shock wave is straightened. The shock wave backout increases slightly, and the Mach cone increases in size. The resistance to movement increases noticeably. The temperature behind the shock wave decreases due to an increase in the gas density and due to the course of endothermic chemical reactions. This is the active thermal protection for supersonic aircraft. The decrease in temperature due to an increase in the gas density can be ignored, since usually a small portion of foreign matter is injected, which also leads to a relatively weak shock wave backout from the streamlined body. Consequently, the cooling of the gas behind the shock wave with active thermal protection occurs mainly due to the course of endothermic chemical reactions. In aviation, a sodium-potassium alloy is used as a liquid metal coolant. The mass of potassium is $77.2 \%$ and the mass of sodium is $22.8 \%$. This alloy has a melting point of minus $12.8^{\circ} \mathrm{C}$ and a high heat transfer coefficient. What is the reason for this? 


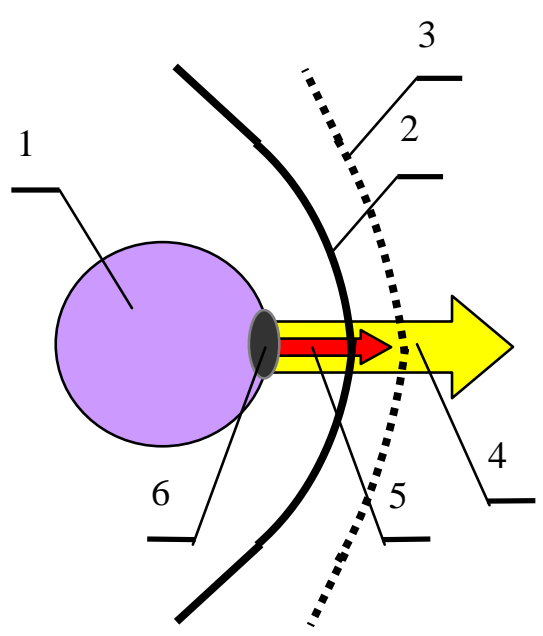

Figure 4-General scheme of injection of the coolant into the front hemisphere: 1 - AES; 2 - shock wave before the injection of the coolant; 3 - after the injection of the coolant; 4 - speed of AES movement; 5 - speed of the injection of the coolant; 6 - hole for the injection of the coolant

Puc. 4 - Общая схема впрыска теплоносителя в переднюю полусферу: 1 - ИСЗ; 2 - ударная волна до впрыска теплоносителя; 3 - после впрыска теплоносителя; 4 - скорость движения ИСЗ; 5 - скорость впрыска теплоносителя; 6 - отверстие для впрыска теплоносителя

Слика 4 - Општа шема убризгавања расхладног средства у предњу хемисферу: 1 - вештачки сателит; 2 - ударни талас пре убризгавања расхладног средства;

3 - после убризгавања расхладног средства; 4 - брзина кретања вештачког сателита; 5 - брзина убризгавања расхладног средства; 6 - отвор за убризгавање расхладног средства

In the liquid state, at the melting point, the bonds between the cluster formations are broken, and at the boiling point, the cluster formations break up into individual molecules. In the solid state, sodium and potassium form a volume-centered structure. This structure is formed by diatomic molecules. The standard enthalpy of atomization at $25{ }^{\circ} \mathrm{C}$ is $91.7 \mathrm{~kJ} / \mathrm{mol}$ for sodium and $90.3 \mathrm{~kJ} / \mathrm{mol}$ for potassium. At a temperature of $298 \mathrm{~K}$ and even at a temperature of $3.000 \mathrm{~K}$, the decomposition of diatomic molecules $\mathrm{Na}_{2}$ and $\mathrm{K}_{2}$, which have a dissociation energy of 0.75 and $0.5 \mathrm{eV}$, respectively, into individual atoms is very unlikely. When a volume-centered cluster decays, it is necessary to break 8 pairs of bonds between diatomic molecules. Taking this into account, it appears that the bond breaking between 
the molecules in the sodium and potassium cluster is 0.119 and $0.117 \mathrm{eV}$, and on average, one molecule of potassium or sodium accounts for approx. $0.059 \mathrm{eV}$.

For a heat-protective coating at a temperature of $3,000 \mathrm{~K}$, ionization of negative nitrogen dioxide ions and triatomic carbon molecules occurs. The degree of their ionization decreases by an amount of $\eta=5.076 \cdot 10^{14} / 2 \cdot 10^{17}=2.54 \cdot 10^{-3}$. The temperature at which the degree of ionization decreases by $2.54 \cdot 10^{-3}$ is determined from the Saha equation

$$
\frac{n_{e} n_{i}}{n_{a}}=c^{\prime} T^{3 / 2} \exp \left(-\frac{E A}{k_{b} T}\right),
$$

where, $\ln c^{\prime}=15,38 E A=2.5 \mathrm{eV}, k_{5}$ is the Boltzmann constant, and $n_{e}$, $n_{i}, n_{a}$ are the concentrations of electrons, ions, and molecules, respectively.

Based on (1), a decrease in the degree of negative ions of triatomic carbon molecules ionization to $2.54 \cdot 10^{-3}$ will occur at a temperature of $1,440 \mathrm{~K}$. This temperature is higher than the boiling point of sodium and potassium. Therefore, clusters of sodium and potassium will not form. The air density behind the shock wave front at an altitude of $50 \mathrm{~km}$

$$
\rho=\rho_{\infty}\left(\frac{\gamma-1}{\gamma+1}+\frac{2}{\gamma+1} \frac{1}{M^{2}}\right)^{-1} \cong 7.49 \cdot 10^{-3} \mathrm{~kg} / \mathrm{m}^{3} .
$$

The number of particles per volume unit will be approx. $3.032 \cdot 10^{23} 1 / \mathrm{m}^{3}$. Each particle of air reduces its kinetic energy by the amount of $k_{5} T_{2}-k_{5} T_{1} \approx 0.143 \mathrm{eV}$, and the number of sodium or potassium molecules that will provide such a reduction in energy equals to $N=0.143 / 0.059 \approx 2,424$. Then the value of the coolant mass, which will reduce the temperature to $1.440 \mathrm{~K}$, will be

$$
\Delta m=\rho N \bar{M} \pi R^{2} \Delta \approx 0.0463 \mathrm{~kg},
$$

that is, only 46.3 grams of a liquid crystal coolant.

At the first cosmic velocity, the emission of negative ions from the surface of the heat-protective coating due to the course of catalytic reactions is not sufficiently intense. However, the energy flux that free electrons transfer due to the ionization of negative ions to the surface of the satellite should not be neglected when the spacecraft is moving at either the first or the second cosmic velocity. 


\section{Interaction of artificial Earth satellites with the environment in the free molecular flow regime. Gretchikhin's effect}

Starting from altitudes of $100 \mathrm{~km}$ and above, the continuum flow changes to the free-molecular regime. In this flight mode, in 1969, the phenomenon of emission of negative oxygen ions with the formation of a double electric layer was predicted, in which powerful violet-blue luminance was formed in the front hemisphere around the AES to flight altitudes of $500 \mathrm{~km}$ with a maximum at an altitude of $110-140 \mathrm{~km}$, mainly in the Earth's shadow zone. In 1971, during the emergency descent of the Soyuz-10 spacecraft in the Earth's shadow zone, cosmonauts visually observed this luminance.

On the basis of theoretical calculations of the thickness of the double electric layer at different altitudes of flight, the concentration of electrons and their energy distribution function were obtained. Based on this, the nonequilibrium radiation of this layer in different spectral lines and molecular bands of nitrogen and oxygen is calculated. The calculation results for a ball with a radius of $1 \mathrm{~m}$ moving at a speed of $7.5 \mathrm{~km} / \mathrm{s}$ are shown in Fig. 5. The luminance of the double electric layer at altitudes below $180 \mathrm{~km}$ significantly exceeds the luminance of the daytime sky and even the polar glows. At a flight altitude of approx. $120 \mathrm{~km}$, the nonequilibrium luminance is comparable to the amount of solar radiation in the range of $400-500 \mathrm{~nm}$ (approx. 9.6 W/m $\mathrm{m}^{2} \mathrm{av}$ ). The luminance changes according to the cosine law depending on the angle of attack.

The maximum energy value of the nonequilibrium luminance corresponds to the flight altitude of approx. $110 \mathrm{~km}$ both in the Earth's shadow zone and in the illuminated zone. In the Earth's shadow zone, the Meynel bands and the first negative system of nitrogen molecules at an altitude of $120 \div 140 \mathrm{~km}$ give a clearly defined maximum and have the highest radiation energy.

In accordance with the predictions of the theory, full-scale measurements were carried out on the long-term space station "Salyut4", specially developed in 1974 by the photometric equipment SFM-4M. At a flight altitude of $350 \mathrm{~km}$, luminance was detected that corresponded in brightness to the theoretical calculation in the spectral lines of oxygen, nitrogen, and in the molecular nitrogen band. The cosine distribution of the luminance over the angle of attack is obtained, as predicted by the theory. The results of these calculations are shown in Figure 5. 


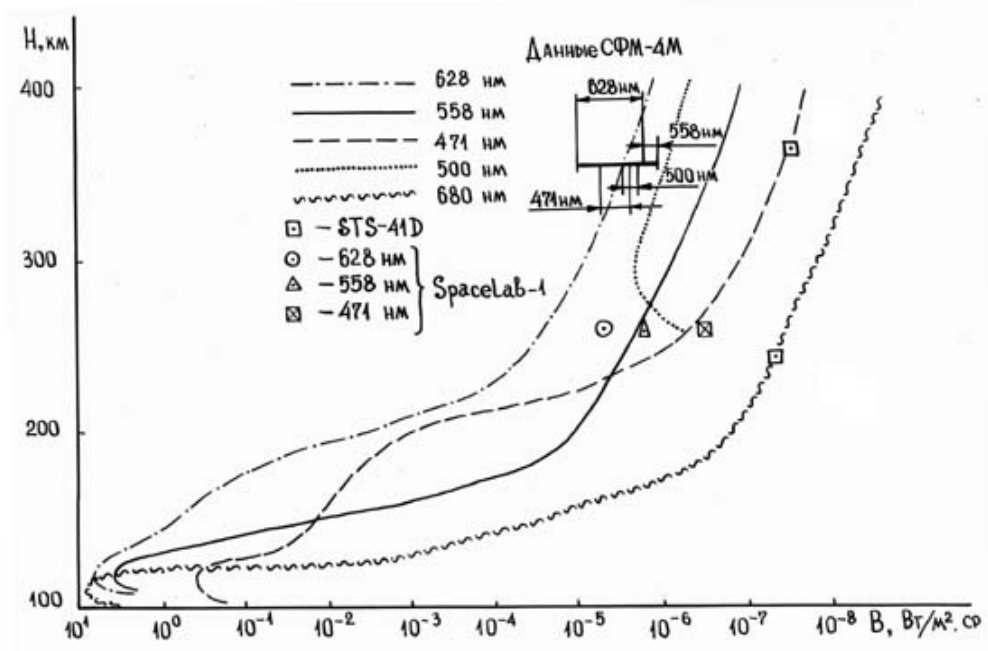

Figure 5 - Calculation of the height range of the brightness of nonequilibrium luminance in comparison with experimental data

Pис. 5 - Расчет высотного хода яркости неравновесного свечения в сравнении с экспериментальными данными

Слика 5 - Израчунавање опсега јачине неравнотежне сјајности у поређењу с експерименталним подацима

Similar results in the United States were obtained on the Shuttle, STS-41, and Spacelab-1 spacecraft (McMahon et al, 1983) and (Prince, 1985) ten years later. The results of these measurements, which coincided with the theoretical calculation, are also shown in Figure 5. The explanation of the observed frontal luminance by chemiluminescence Prince (Prince, 1985) and Engebretson and Hedin (Engebretson \& Hedin, 1986) and the Papadopoulos discharge model (Papadopoulos, 1983 ) is not able to withstand criticism.

Another phenomenon caused by the interaction of a solid body with particles of near-Earth space with the participation of negative ions should be noted. Under dynamic equilibrium conditions, the flow of ambient electrons is partially compensated by the flow of negative ions that escape into the surrounding space. As a result of the chemical reactions of negative ion ionization, superthermal electrons with an energy in the range of $0.4 \ldots 3.6 \mathrm{eV}$ appear. Such electrons lead to the effective excitation of the energy levels of atoms and molecules, 
the spontaneous emission of which for forbidden oxygen lines is significantly delayed. Therefore, at some distance from the spacecraft, a pink-red halo should appear, and the satellite trail should also have the same color. A pink-red halo was indeed detected with a maximum at a distance of approx. $1 \mathrm{~m}$ from the spacecraft (Papadopoulos, 1983).

In outer space, plasma and ion engines are used to perform various maneuvers. When such engines are running, the spacecraft is negatively charged to significant potentials. The movement of a charged body in a vacuum has a noticeable friction. Let us consider this phenomenon in more detail.

\section{Interaction of charged particles with vacuum}

When charged bodies move in vacuum, their kinetic energy decreases due to the vacuum polarization (Gretchikhin, 2018b). Spacecraft that use plasma or ion engines are effectively charged, and there is noticeable friction against vacuum. A charged spherical body with the radius $R$ when moving in vacuum creates a spherically symmetric electric field, and this field polarizes the quantons ${ }^{1)}$ of the physical vacuum. As a result, at a distance $r$ from the charged body in the spherical volume $4 \pi r^{2} d r$ element, each quanton is polarized to form a dipole electric moment. The energy spent on creating such a dipole will be

$$
\Delta U=-p_{\ni} E_{\ni}
$$

where $p_{\ni}$ is the induced dipole electric moment of the quanton and $E_{\text {э }}$ is the electric field strength generated by a charged cosmic body. An increase in the intensity of the external field increases the internal energy of the quanton, and a decrease in the external field leads to dipole-dipole radiation of the quanton energy into the surrounding space.

The mechanism of such friction has yet to be studied in detail.

It is especially important to justify the influence of negative ions on the processes of energy release in the boundary layer during the launching and the reentry of spacecraft.

\footnotetext{
1) Full justification of the quanton is given in work (Gretchikhin, 2016).
} 


\section{Explosion of the boundary layer. Gretchikhin's theory}

During the exploration of space, there was a problem of retrieving spacecraft reentering the Earth's atmosphere at the first and the second cosmic velocity. The formation of powerful shock waves leads to a noticeable heating of the surface of the descending spacecraft due to convective and radiative heat exchange with the high-temperature gas behind the shock wave. To ensure the safety of the descending spacecraft, a heat-protective coating was used, the destruction of which did not allow heat energy to penetrate into the spacecraft. A mixture of air heated by the shock wave with debris of the thermal-protective coating emerges between the shock wave and the surface of the descending spacecraft. The chemical reactions taking place in such a mixture have been beyond our vision for a long time.

Depending on the type of the chemical reaction (endothermic or exothermic), additional cooling or heating of the heated air behind the shock wave takes place. Exothermic reactions with the release of energy are especially dangerous. Therefore, let us have a closer look at the dynamics of the destruction of the descending spacecraft surface determining the number of atoms and molecules that mix with the heated air behind the shock wave, and how much energy is released in various exothermic reactions. It is necessary to find out what energy is released and how it will affect the dynamics of the descending spacecraft flight. It is important to find out what happens when space bodies descend at the first and, especially, at the second cosmic velocity.

When a spacecraft descends from the orbit, a shock wave begins to form at an altitude of approx. $80 \mathrm{~km}$. As the altitude decreases, the velocity increases slightly, reaching a maximum at an altitude of $40 \mathrm{~km}$. The change in flight velocity with altitude for the descending Soyuz series spacecraft is given in Table 1. Flight velocities are much higher than the velocity of sound. In this case, the density, pressure, and temperature of the gas in the shock wave can be determined by the formulas (Gretchikhin et al, 2012). 
Table 1 - Parameters of the air behind the shock wave at the first and second cosmic velocity

Таблица 1 - Параметры воздуха за ударной волной при первой и второй космических скоростях

Табела 1 - Параметри ваздуха иза ударног таласа при првој и другој космичкој брзини

\begin{tabular}{|c|c|c|c|c|c|}
\hline \multirow{2}{*}{ Parameters } & \multicolumn{5}{|l|}{ Altitude, km } \\
\hline & 40 & 50 & 60 & 70 & 80 \\
\hline $\begin{array}{l}\text { First cosmic } \\
\text { velocity, } M \\
\text { Second cosmic } \\
\text { velocity, } M\end{array}$ & $\begin{array}{l}22.35 \\
33.92\end{array}$ & $\begin{array}{l}23.82 \\
35.56\end{array}$ & $\begin{array}{l}25.34 \\
37.04\end{array}$ & $\begin{array}{l}25.80 \\
38.11\end{array}$ & $\begin{array}{l}26.42 \\
39.39\end{array}$ \\
\hline Density, $\rho / \rho_{\infty}$ & $\begin{array}{l}5.940 \\
5.974\end{array}$ & $\begin{array}{l}5.947 \\
5.976\end{array}$ & $\begin{array}{l}5.954 \\
5.978\end{array}$ & $\begin{array}{l}5.955 \\
5.979\end{array}$ & $\begin{array}{l}5.957 \\
5.981\end{array}$ \\
\hline Density, $\rho / \rho_{\infty}$ & $\begin{array}{l}584 \\
1.343\end{array}$ & $\begin{array}{l}663 \\
1.476\end{array}$ & $\begin{array}{l}750.1 \\
1.602\end{array}$ & $\begin{array}{l}777.6 \\
1.695\end{array}$ & $\begin{array}{l}815 \\
1.811\end{array}$ \\
\hline $\begin{array}{l}\text { Shock wave } \\
\text { backout distance, } \\
m\end{array}$ & $\begin{array}{l}0.112 \\
0.1115\end{array}$ & $\begin{array}{l}0.112 \\
0.1115\end{array}$ & $\begin{array}{l}0.1119 \\
0.11147\end{array}$ & $\begin{array}{l}0.1118 \\
0.11145\end{array}$ & $\begin{array}{l}0.1118 \\
0.1114\end{array}$ \\
\hline $\begin{array}{l}\text { Temperature at } \\
\text { the wave front, } K\end{array}$ & $\begin{array}{l}25.746 \\
58.913\end{array}$ & $\begin{array}{l}27.532 \\
61.013\end{array}$ & $\begin{array}{l}29.357 \\
62.423\end{array}$ & $\begin{array}{l}28.595 \\
62.096\end{array}$ & $\begin{array}{l}28.057 \\
62.081\end{array}$ \\
\hline $\begin{array}{l}\text { Temperature of } \\
\text { the shock- } \\
\text { compressed gas, } \\
K\end{array}$ & $\begin{array}{l}6.437 \\
14.728\end{array}$ & $\begin{array}{l}6.883 \\
15.253\end{array}$ & $\begin{array}{l}7.339 \\
15.606\end{array}$ & $\begin{array}{l}7.149 \\
15.524\end{array}$ & $\begin{array}{l}7.014 \\
15.520\end{array}$ \\
\hline $\begin{array}{l}\text { Effective } \\
\text { temperature of } \\
\text { the compressed } \\
\text { gas, } K\end{array}$ & $\begin{array}{l}6.434 \\
14.725\end{array}$ & $\begin{array}{l}6.880 \\
15.250\end{array}$ & $\begin{array}{l}7.337 \\
15.602\end{array}$ & $\begin{array}{l}7.146 \\
15.521\end{array}$ & $\begin{array}{l}7.012 \\
15.517\end{array}$ \\
\hline $\begin{array}{l}\text { Convective heat } \\
\text { transfer, } \mathrm{W} / \mathrm{m}^{2}\end{array}$ & $\begin{array}{l}2.01 \cdot 10^{7} \\
7.78 \cdot 10^{7}\end{array}$ & $\begin{array}{l}5.48 \cdot 10^{6} \\
1.82 \cdot 10^{7}\end{array}$ & $\begin{array}{l}2.24 \cdot 10^{6} \\
7.735 \cdot 10^{7}\end{array}$ & $\begin{array}{l}3.85 \cdot 10^{5} \\
1.24 \cdot 10^{6}\end{array}$ & $\begin{array}{l}5.57 \cdot 10^{4} \\
2.02 \cdot 10^{5}\end{array}$ \\
\hline $\begin{array}{l}\text { Penetration } \\
\text { depth, } m\end{array}$ & $\begin{array}{l}7.51 \cdot 10^{-2} \\
0.169\end{array}$ & $\begin{array}{l}1.98 \cdot 10^{-2} \\
4.395 \cdot 10^{-2}\end{array}$ & $\begin{array}{l}7.81 \cdot 10^{-3} \\
1.68 \cdot 10^{-2}\end{array}$ & $\begin{array}{l}1.36 \cdot 10^{-3} \\
3.00 \cdot 10^{-3}\end{array}$ & $\begin{array}{l}2.00 \cdot 10^{-4} \\
4.45 \cdot 10^{-4}\end{array}$ \\
\hline $\begin{array}{l}\text { Radiative heat } \\
\text { transfer, } W / m^{2}\end{array}$ & $\begin{array}{l}4.86 \cdot 10^{6} \\
1.33 \cdot 10^{8}\end{array}$ & $\begin{array}{l}6.35 \cdot 10^{6} \\
1.533 \cdot 10^{8}\end{array}$ & $\begin{array}{l}8.21 \cdot 10^{6} \\
1.68 \cdot 10^{8}\end{array}$ & $\begin{array}{l}7.39 \cdot 10^{6} \\
1.65 \cdot 10^{8}\end{array}$ & $\begin{array}{l}6.85 \cdot 10^{6} \\
1.64 \cdot 10^{8}\end{array}$ \\
\hline $\begin{array}{l}\text { Electron flux heat } \\
\text { transfer, } W / \mathrm{m}^{2}\end{array}$ & $\begin{array}{l}2.56 \cdot 10^{7} \\
8.9 \cdot 10^{7}\end{array}$ & $\begin{array}{l}6.98 \cdot 10^{6} \\
2.31 \cdot 10^{7}\end{array}$ & $\begin{array}{l}2.85 \cdot 10^{6} \\
8.86 \cdot 10^{6}\end{array}$ & $\begin{array}{l}4.90 \cdot 10^{5} \\
1.56 \cdot 10^{6}\end{array}$ & $\begin{array}{l}7.09 \cdot 10^{4} \\
2.34 \cdot 10^{5}\end{array}$ \\
\hline $\begin{array}{l}\text { Pressure in the } \\
\text { boundary layer, } \\
\mathrm{Pa}\end{array}$ & $5.485 \cdot 10^{10}$ & $1.62 \cdot 10^{10}$ & $5.938 \cdot 10^{9}$ & $7.088 \cdot 10^{9}$ & $1.059 \cdot 10^{10}$ \\
\hline $\begin{array}{l}\text { Energy released } \\
\text { on the surface, } J\end{array}$ & $4.477 \cdot 10^{6}$ & $1.092 \cdot 10^{6}$ & $1.096 \cdot 10^{5}$ & $1.367 \cdot 10^{5}$ & $1.921 \cdot 10^{5}$ \\
\hline
\end{tabular}




$$
\rho=\rho_{\infty}\left(\frac{\gamma-1}{\gamma+1}+\frac{2}{\gamma+1} \frac{1}{M^{2}}\right)^{-1} ; \quad P=P_{\infty}\left(1+\frac{2 \gamma}{\gamma+1} M^{2}\right) ; \quad T=T_{0} \frac{\rho_{\infty}}{\rho} \frac{P}{P_{\infty}}
$$

where $\gamma$ is the ratio of the specific heat capacities of the gas at constant volume and constant pressure; $M$ is the Mach number. Specific calculations for a sphere with a radius of $1 \mathrm{~m}$ at different altitudes are given in Table 1. Directly in the front of the shock wave at all altitudes of flight in the compression shock wave, the temperature is very high.

The backout distance of the shock wave from the nose of a hypersonic vehicle of a given geometry for a direct shock wave can be determined as follows (Gretchikhin et al, 2012):

$$
\Delta=R \frac{\rho_{\infty}}{\rho}\left(1-\frac{\rho_{\infty}}{\rho}+\sqrt{\frac{8}{3} \frac{\rho_{\infty}}{\rho}}\right)^{-1} .
$$

High temperatures behind the direct shock wave cause significant heating of the air atmosphere. Diatomic molecules of nitrogen and oxygen completely dissociate. Since this requires energy, the temperature in the shock wave decreases. The number of particles doubles. Also, the ionization of oxygen and nitrogen atoms takes place, which leads to a decrease in the adiabatic index. Taking into account the dissociation process, the temperature of the air behind the shock wave (Zeldovich \& Raizer, 1966) is

$$
T_{B}=T_{0} \frac{\rho_{\infty}}{\rho} \frac{P}{P_{\infty}} \alpha .
$$

At temperatures above $10.000 \mathrm{~K}$, nitrogen and oxygen molecules will dissociate completely, and then $\alpha \cong 0.5$. As a result of ionization, the air temperature will decrease due to the formation of plasma. Then (Zeldovich \& Raizer, 1966)

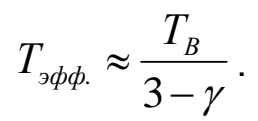

For dry air at a temperature of $2,000 \mathrm{~K}$, the adiabatic index is $\gamma=1.088$. For higher temperatures, we can assume $\gamma \approx 1$.

The results of calculation according to (7) are shown in Table 1. The temperature of the shock-compressed gas is high, and such a gas should be considered as plasma. Charged particles are produced in plasma as a result of ionization of predominantly negative ions. Therefore, thermal energy is transferred to the surface of the descending spacecraft due to convective and radiative heat transfer, as well as due to the flow of 
electrons when passing through the electrical double layer. The input data on the energies of dissociation of diatomic molecules, the detachment of atoms in triatomic molecules, and the electron affinity for aluminum are given in Table 2 .

Table 2 - Energy of dissociation and electron separation in a negative aluminum ion

Таблица 2 - Энергия диссоциации

и отрыва электрона в отрицательном ионе алюминия

Табела 2 - Енергија дисоцијације и сепарације електрона у негативном јону алуминијума

\begin{tabular}{|l|l|l|}
\hline \multirow{2}{*}{$\begin{array}{l}\text { Atoms, } \\
\text { molecules }\end{array}$} & \multicolumn{2}{|l|}{ Energy, eV } \\
\cline { 2 - 3 } & $\begin{array}{l}\text { dissotiation } \\
\text { of }\end{array}$ & $\begin{array}{l}\text { electron } \\
\text { detachment }\end{array}$ \\
\hline$A l_{3}^{-}$ & $\sim 0.406$ & $\sim 1.785$ \\
\hline$A l_{2}^{-}$ & 2.0 & 2.42 \\
\hline$A l^{-}(3 \mathrm{P})$ & - & 0.44 \\
\hline$A l^{-}(1 \mathrm{D} 2)$ & - & 0.33 \\
\hline$A l O_{-}$ & 5.14 & 3.6 \\
\hline$A l O_{2}$ & $\sim 2.51$ & 4.1 \\
\hline \multicolumn{2}{|l}{} \\
\hline
\end{tabular}

The " $\sim$ " symbol means that this value is obtained by extrapolation

\section{Convective heat transfer}

In convective heat transfer, energy is transferred by the collision of heated gas particles with the surface of the spacecraft. Each solid is formed by an intercluster lattice structure. The clusters themselves are formed by diatomic or triatomic molecules. What are clusters of diatomic molecules with experimental justification is considered in (Gretchikhin et al, 2015a) and of triatomic molecules in (Gretchikhin et al, 2015b). Aluminum clusters are formed by triatomic molecules as shown in Fig. 6. 


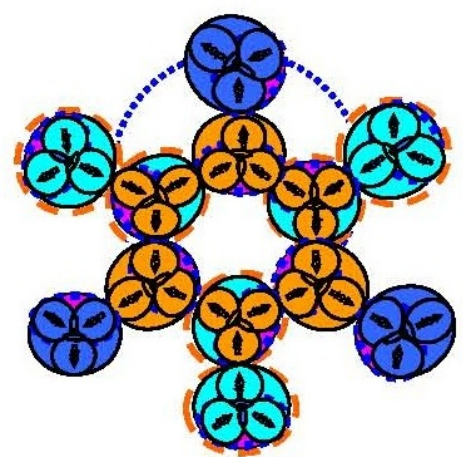

a)

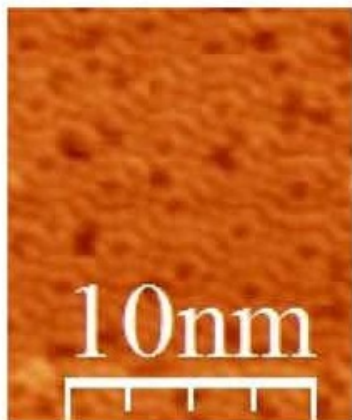

b)

Figure 6-Cluster of triatomic molecules: a) theoretical calculation; b) experimental confirmation Puc. 6 - Кластер трехатомных молекул: a) теоретический расчет; б) экспериментальное измерение Слика 6 - Кластер триатомских молекула: а) теоријско израчунавање;

б) експериментална потврда

The main cluster is highlighted in the center, and the highlighted triatomic molecules have broken bonds in diatomic molecules. As a result, some triatomic molecules in the center have an excess negative charge, and others - a positive charge. In Fig. 6, these molecules are shown in different colors. The clusters are flat and interact with each other by cohesion, and the solid resembles a layer cake. The formation of clusters occurs by combining the molecules of the first and the second coordination layers (Gretchikhin, 2004) and (Gretchikhin, 2008). The energy from the heated gas is transferred to the spacecraft surface by the collision of air molecules with the solid clusters. Thermal random velocity of the heated air

$$
v_{T}=\sqrt{\frac{8 k_{b} T_{a}}{\pi m_{a}}},
$$

where $k_{b}$ is the Boltzmann constant, $T_{a}$ is the temperature of shockcompressed air, and $m_{a}$ is the average weight of air molecules.

Only $1 / 6$ of air molecules collide directly with the surface. The molecules collide with the clusters of the solid. In convective heat transfer, only the surface layer of cluster formations is excited. Clusters of aluminum are formed by triatomic molecules, producing a facecentered crystalline structure. Since there is a hollow in the center of a cluster, which does not receive the impacts of external particles, only $9 / 10$ of the total flow of external particles acting on the surface of the 
spacecraft is received. The second coordination layer of the cluster is destroyed before the melting temperature is reached, and the first coordination layer is destroyed after the melting temperature is reached. Near the boiling temperature, the number of molecules in a cluster is approx. 6 (Gretchikhin, 2008). When air molecules collide with clusters on the surface of a solid, the energy transfer ratio is (Gretchikhin, 2004)

$$
\eta=\frac{4 m_{a} m_{S}}{\left(m_{a}+m_{S}\right)^{2}},
$$

where $m_{b}$ is the weight of a solid cluster and $m_{S}$ is the average effective mass of air molecules in the atomic form equal to approx. 29/2.

Taking into account (8) and (9), the convective energy flux to the solid surface is

$$
J_{C}=\frac{9}{120} \rho v_{T}^{3} \eta,
$$

where $\rho$ is the density of the air behind the shock wave front.

Energy is transferred to the area of one molecule of a solid body

$$
E_{m}=\frac{10}{9} J_{C} \pi r_{m}^{2} \text {. }
$$

The radius of a triatomic molecule $r_{m} \approx 2.155 r_{a}$ and $r_{a}$ is the radius of an atom of the solid, obtained by the radiographic method. At each altitude, an aluminum object loses its weight to a depth

$$
d h=2 r_{a} \frac{E_{m}}{E_{c b}},
$$

where $E_{c b \text {. }}$ is the molecular bond energy, determined by the boiling temperature. For aluminum, this value is $3.389 \cdot 10^{-20} \mathrm{~J}$. The results of calculation of the depth of complete dissociation of the main clusters according to (12) are given in Table 1 . It takes only $3 / 4$ of the total heat flux in convective heat transfer. The remaining part of the convective energy flux is absorbed by intercluster hollows preventing the noticeable destruction of the solid (see Fig. 6).

As a result of destruction, the total number of triatomic aluminum molecules is formed as negative ions

$$
N_{A l}^{-}=2 \pi r^{2} d h \frac{\rho_{A l}}{m_{b}},
$$


and the concentration of negative ions of triatomic aluminum molecules in the shock-compressed gas

$$
n_{A l}^{-}=\frac{N_{A l}^{-}}{2 \pi r^{2} d h} .
$$

The temperature of gas of triatomic aluminum molecules is equal to the boiling temperature, i.e. $T_{\text {кип }}=2,743 \mathrm{~K}$.

The total number of air molecules in the shock-compressed air behind the shock wave

$$
N_{a}=2 \pi r^{2} d h \rho / m_{a},
$$

and the molecules are at the temperature determined according to (7).

The average effective temperature will be

$$
T_{\text {эфф. }}=\left(\frac{T_{\text {кun. }} N_{A l}+T_{0} N_{a}}{N_{A l}+N_{a}}\right) \text {. }
$$
occurs:

At this temperature, the following aluminum combustion reactions

$$
\begin{aligned}
& A l_{3}^{-}+O \Leftrightarrow A l_{2}+A l O+e+1.134 \mathrm{eV} ; \quad \mathrm{Al}_{2}+O \Leftrightarrow A l+A l O+3.14 \mathrm{eV} \\
& A l+O \Leftrightarrow A l O+5.14 \mathrm{eV} .
\end{aligned}
$$

The total energy released during the complete combustion of triatomic aluminum molecule is $9.414 \mathrm{eV}$, and the energy of the electron gas corresponds to the effective temperature of the plasma determined according to (16). The electron gas ionizes negative ions of aluminum molecules by electron impact:

$$
A l_{3}^{-}+e \Leftrightarrow A l_{3}+2 e \text {. }
$$

In this case, the temperature of the electron gas is (Gretchikhin \& Kudrjashov, 1970)

$$
T_{e}=0.55 \cdot I A \cdot 11600=11388 \mathrm{~K} .
$$

The electron gas produced from the ionization of negative ions is nonequilibrium. Consequently, the plasma of the shock-compressed gas at such temperatures of the electron gas and a sufficiently high temperature of the atomic gas has a noticeable radiation capacity. In this case, radiative heat transfer must be considered. 


\section{Radiative heat transfer}

For dense plasma, the radiation of individual atoms and molecules from the inner layers is intensely absorbed inside the plasma, and thermal radiation can be considered as black body radiation, taking into account the emissivity factor. For evaluations, let us assume that the emissivity factor $\kappa=0.5$. Then

$$
J_{L}=\kappa \sigma_{S} T_{\ni \phi \phi}^{4},
$$

where $\sigma_{S}=5.67 \cdot 10^{-8} \mathrm{~W} \cdot \mathrm{m}^{-2} \mathrm{~K}^{-4}$ is the Stefan constant.

The results of the obtained radiant energy fluxes at different altitudes are given in Table 1 . The energy flux in radiative heat transfer penetrates through the solid to the skin layer depth. If the solid receives external radiation, then the thickness of the skin layer can be determined according to the formula (Gretchikhin, 2016):

$$
\Delta r=\sqrt{\frac{\rho_{\ni}}{\pi f \mu}},
$$

where $f$ is the electromagnetic radiation frequency, $\mu$ is the magnetic permeability, and $\rho_{\ni}$ is the electrical conductivity of the solid.

In formula (21), the frequency of thermal radiation $f$ corresponds to the maximum of the radiation flux density distribution function per unit frequency interval according to the Planck formula. Therefore, the obtained specific values of the absorption thickness appeared to be much smaller than the thickness of the aluminum cluster. This means that all incident radiation is completely reflected from an aluminum surface with a close-packed structure (Fig. 6b). The absorption of the radiant flux takes place in the defects of the crystalline structure and in the centers of cluster formations. For an ideal surface, absorption occurs only by the centers of cluster formations and is approximately $1 / 12$, and as the surface transits to the liquid state, the ratio of the absorbed radiant flux energy increases, and the radiant flux contributes to the destruction of both a metal and a dielectric moving object.

With the emission of molecules with electron affinity from the spacecraft surface, an electric double layer is formed. At some distance, negative ions are ionized, and the produced electrons, passing through the potential difference of the double electric layer, bombard the surface and additionally increase the energy flux to the spacecraft surface. 


\section{Electron impact energy flow}

Negative ions from the aluminum surface are emitted in the form of triatomic molecules at the boiling temperature. Ionization of negative ions of aluminum molecules takes place due to the occurrence of reactions (17) and (18). Both reactions take place in the gas-vapor phase. As a result of the emission of negative ions from the aluminum surface, the electric double layer is formed. The potential difference in the electric double layer is determined by the molecular energy at the boiling temperature. For aluminum, the potential difference of the double layer is

$$
\Delta U=\frac{k_{b} T_{\text {кun. }}}{e} V .
$$
be

The flux of energy carried by electrons to the aluminum surface will

$$
J_{e}=n_{A l}^{-} v_{e} k_{b} T_{\kappa и п ~},
$$

and the total energy transferred to the surface by electron impact will be

$$
\Delta E_{2}=J_{e} 2 \pi r^{2} d h .
$$

The resulting energy on the metal surface of the incoming solid is the sum of the convective and electronic heat transfer, i.e. $\Delta E=\Delta E_{1}+\Delta E_{2}$.

The pressure that arises in the boundary layer is

$$
P=\frac{\Delta E}{2 \pi r^{2} d l} .
$$

The values of pressure arising in the boundary layer at different altitudes are given in Table 1. Such pressures occur during the explosion of explosives (Gretchikhin, 2008). The explosion in the boundary layer has such high intensity that the entire structure of the spacecraft breaks down into small parts. This process is shown in Fig. 7 and Fig. 8 (Gretchikhin, 2008). 


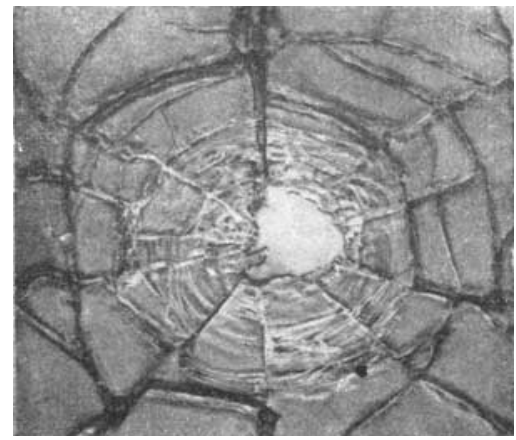

Figure 7 - Fracture pattern in a glass plate exposed to an explosion pressure of $2.8 \cdot 10^{9} \mathrm{~Pa}$

Pис. 7 - Изображение разрушения стеклянной пластины под давлением взрыва $2.8 \cdot 10^{9} \mathrm{~Pa}$

Слика 7 - Начин лома стаклене плоче изложене притиску експлозије од $2,8 \times 10^{9} \mathrm{~Pa}$

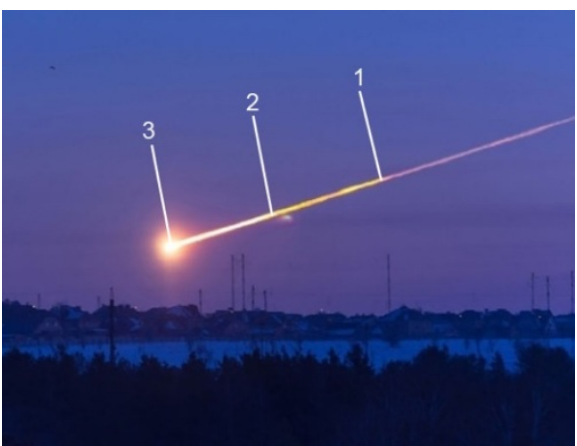

Figure 8-Meteor flight path, Chelyabinsk, 2013 :

1 - the 1st explosion - cracking;

2 - the 2nd explosion - breaking up into separate parts;

3 - the 3rd explosion - the most powerful explosion: the component parts are scattered over long distances from each other

Puс. 8 - Вхождение метеора под Челябинском, 2013: 1 - первый взрыв - растрескивание;

2 - второй взрыв - разделение на отдельные части;

3 - третий взрыв - наиболее мощный: составные части разбрасывает на большие расстояния друг от друга

Слика 8 - Путања лета метеора, Чељабинск, 2013: 1 - прва експлозија - пуцање;

2 - друга експлозија - распадање на делове;

3 - трећа, најснажнија експлозија - расејавање фррагмената на великим удаљеностима 
A sublimation spot appears in the explosion center. An explosion on the surface of a solid causes not only sublimation, but also cracking of the entire array in the form of radial cracks, as well as formation of cylindrical and spherical cracks inside the solid. This stops the flow of energy to the surface. As a result, a sequence of explosions occurs, causing breakdown of solid monolith into separate small parts. The effective interaction surface between the solid and the shockcompressed air increases. Therefore, there are successive explosions with increasing intensity. The fire cloud of explosion also grows in size. Finally, small fragments of the spacecraft fall to the Earth. This was experimentally confirmed when the long-term orbital station MIR-1, with the main structure made of duralumin without a thermal-protective coating, entered dense atmospheric layers. The sequence of explosions occurred when a meteor fell near Chelyabinsk. There were three consecutive explosions, and the last explosion was the most powerful one.

Thus, in the exploration of outer space, humanity is at the initial stage. Only the first cosmic velocity has been overcome. The exploration of the Moon and the nearest planets of the solar system involves overcoming the second cosmic velocity. The "Apollo-11" returned from the Moon by mere chance. It is necessary to carefully study the entire dynamics of the flight and the nature of the interaction with the Earth's atmosphere. Until the entire dynamics of the flight with the second cosmic velocity is fully explained, it is still necessary to use only automatic machines.

\section{Conclusions}

Let us briefly formulate the obtained phenomena and the results in the exploration of the outer space:

1. For the descent trajectory of the spacecraft with the structure made of duralumin without a thermal-protective coating at the first and second cosmic velocities at altitudes of 80 to $40 \mathrm{~km}$, data were obtained on the increase in density, pressure and temperature behind the shock front, as well as the backout of the shock wave from the surface of the descending spacecraft.

2. The effective temperature of the shock-compressed gas reaches its maximum value of $7,340 \mathrm{~K}$ for the first cosmic velocity and 15,602 $\mathrm{K}$ for the second cosmic velocity at an altitude of approx. $60 \mathrm{~km}$. At an altitude of $80 \mathrm{~km}$, it is $7.000 \mathrm{~K}$ and $15.500 \mathrm{~K}$, respectively, and at an altitude of $40 \mathrm{~km}-6.400 \mathrm{~K}$ and $14.700 \mathrm{~K}$. 
3. Calculations were made of the energy fluxes to the surface of the spacecraft for every $10 \mathrm{~km}$ in the altitude range of 40 to $80 \mathrm{~km}$, for convective and radiative heat transfer, as well as for the impact of electrons produced due to ionization of negative ions. In this case, at the first cosmic velocity, the greatest energy flux is realized under the influence of an electron flux, and at the second cosmic velocity, radiative heat transfer appeared to be the most significant.

4. The increase in pressure in the boundary layer at the spacecraft surface at the first and second cosmic velocities was calculated taking into account the burning of negative ions of triatomic molecules of aluminum with the formation of $\mathrm{AlO}$ molecules. At all considered altitudes, the pressure rises instantly to a value of $10^{9}$ to $10^{11} \mathrm{~Pa}$ and more, which is typical for explosions of various explosives. Each subsequent explosion produces shock waves in the surrounding atmosphere and compressive waves in the entire structure of the spacecraft. The descending spacecraft cracks, and its entire structure breaks down into parts. The area of interaction increases sharply, and each subsequent explosion is greater in intensity and size. After each explosion, the energy flux to the surface stops due to shielding for all types of heat transfer. After the dispersion of the explosion products, an intense flux of energy reappears on the surface of the descending spacecraft and a new explosion occurs. As a result, the last most intense explosion occurs at an altitude of approx. $40 \mathrm{~km}$, after which individual fragments of the spacecraft fall to the Earth. All this was clearly visible during the descent of the long-term orbital station "MIR-1" and when a meteor entered near Chelyabinsk.

5. The situation is slightly better for spacecraft with thermal protection, but is still very dangerous. Descents must not be carried out at low g-forces. Even at the first cosmic velocity, the descent phase at an altitude of 80 to $40 \mathrm{~km}$ should be passed as quickly as possible.

6 . When descending spacecraft and meteors enter the atmosphere at the second or greater cosmic velocity, the temperature of the shockcompressed gas reaches more than $15.000 \mathrm{~K}$. At such temperatures, the power of the explosions increases by an order of magnitude. This results in falling of small debris and even individual dust particles to the Earth, which was observed when the Chelyabinsk meteor entered the Earth's atmosphere.

To summarize for meteors entering the Earth's atmosphere:

a) At an altitude of about $80 \mathrm{~km}$, an explosion occurs due to the formation of shock waves and combustion of negative ions, which leads to the cracking of the entire monolith of the initial meteor. 
b) After the second explosion, the monolith breaks up along cracks (into separate unconnected parts) and the area from which negative ions emit dramatically increases. The concentration of negative ions in the boundary layer sharply increases so that the power of the next explosion increases as well.

c) After the third very powerful explosion, individual pieces of the disintegrated meteor scatter in all directions (All three explosions with increasing power were witnessed when the Chelyabinsk meteor entered the Earth's atmosphere).

d) The individual parts of the meteor still perform supersonic motion, but at different speeds and with a chaotic distribution in space. Around each of them there are explosions, but with less power and not connected to each other in time. A hissing effect occurs, which was witnessed when the Tunguska meteor entered the Earth's atmosphere.

Meteors flying around the Sun in great numbers are very dangerous for the Earth. They are charged and therefore broke in the physical vacuum (Gretchikhin, 2018b), and may eventually fall to the Earth. For the planet, it could have disastrous consequences that might be more terrible than the consequences of an atomic bomb explosion.

The current state of the planet Mars is proof of this. It is believed that long time ago the explosion of Phaeton led to the formation of the asteroid belt. Consequently, the fall of asteroids on the planet Mars led to Phaeton's destruction. That is why today the surface of Mars is reminiscent of impact craters of the Moon and the deserts and polar ice caps of the Earth.

\section{References}

Babichev, A.P., Babushkina, N.A., Bratkovskij, A.M. et al. 1991. Physical values: Handbook. Moscow: Energoatomizdat (in Russian). ISBN: 5-283-040135 (In the original: Бабичев, А.П., Бабушкина, Н.А., Братковский, А.М. и др. 1991. Физические величины. Справочник. Москва: Энергоатомиздат. ISBN: 5-283-04013-5).

Elanskij, G.N. 1991. Stroenie i svojstva metallicheskih rasplavov. Moscow: Metallurgija (in Russian). ISBN: 5-229-00723-0 (In the original: Еланский, Г.Н. 1991. Строение и свойства металлических расплавов. Москва: Металлургия. ISBN: 5-229-00723-0)

Engebretson, M.J. \& Hedin, A.E. 1986. DE-2 mass spectrometer observations relevant to the Shuttle glow. Geophysical Research Letters, 13(2), pp.109-112. Available at: https://doi.org/10.1029/GL013i002p00109. 
Gretchikhin, L.I. 1986. Neravnovesnoe opticheskoe izluchenie vozdushnyh i kosmicheskih letatel'nyh apparatov. Ph.D. thesis. Minsk, Belarus: Belarusian Polytechnic Institute (in Russian). (In the original: Гречихин, Л.И. 1986. Неравновесное оптическое излучение воздушных и космических летательных аппаратов. Докторская диссертация. Минск, Беларусь: Белорусский политехнический институт).

Gretchikhin, L.I. 2003. Vzaimodejstvie tverdogo tela s okruzhajushhej sredoj v rezhime svobodnomolekuljarnogo obtekanija (jeffekt Gretchikhina). In The First Belarusian Space Congress, Minsk, Belarus, pp.31-33, October 28-30 (in Russian). (In th eoriginal: Гречихин, Л.И. 2003. Взаимодействие твердого тела с окружающей средой в режиме свободномолекулярного обтекания (эфффект Гречихина). В: Первый Белорусский космический конгресс, г. Минск, Беларусь, с.31-33, 28-30 октября).

Gretchikhin, L.I. 2004. Physics of nanoparticles and nanotechnologies. General foundations, mechanical, thermal and emission properties. Minsk: Tekhnoprint (in Russian). (In the original: Гречихин, Л.И. 2004. Физика наночастиц и нанотехнологий. Общие основы, механические, тепловые и эмиссионные свойства. Минск: УП «Технопринт»).

Gretchikhin, L.I. 2008. Nanochasticy i nanotehnologii. Minsk, Belarus: Pravo i jekonomika (in Russian). (In the original: Гречихин, Л.И. 2008. Наночастицы и нанотехнологии. Минск, Беларусь: Право и экономика).

Gretchikhin, L.I. 2016. Osnovy radiosvjazi. Minsk, Belarus: National Library of Belarus (in Russian). (In the original: Гречихин, Л.И. 2016. Основы радиосвязи. Минск, Беларусь: Национальная библиотека Беларуси).

Gretchikhin, L.I. 2018a. Negative ions in space exploration. In: The Eight World Congress "Aviation in the XXI-st century - Safety in Aviation and Space Technology", Kiev, Ukraine, pp.2.3.29-2.3.37, October 10-12 [online]. Available at: http://conference.nau.edu.ua/index.php/Congress/Congress2018/paper/viewFile/5 471/4035 [Accessed: 28 April 2021].

Gretchikhin, L.I. 2018b. Complex charge and electron spin. Aeronautics and Aerospace Open Access Journal, 2(6), pp.424-428. Available at: https://doi.org/10.15406/aaoaj.2018.02.00074.

Gretchikhin, L.I. 2018c. Negative ions and their role in the development of science and technology. Vojnotehnički glasnik/Military Technical Courier, 66(4), pp.847-863. Available at: https://doi.org/10.5937/vojtehg66-17262.

Gretchikhin, L.I. 2019. Formation of negative ions an the surface of a solid body and their influence on the thermoelectronic and autoelectronic emission of free electrons. American Journal of Applied Scientific Research, 5(3), pp.47-55. Available at: https://doi.org/10.11648/j.ajasr.20190503.11.

Gretchikhin, L.I. \& Kudrjashov, V.V. 1970. Srednejeffektivnaja temperatura jelektronnogo gaza, obrazovannogo pri udarnoj ionizacii. Izvestiya vuzov. Fizika, 9, pp.7-16 (in Russian) (In the original: Гречихин, Л.И, Кудряшов, В.В. 1970. Среднеэффективная температура электронного газа, образованного при ударной ионизации. Известия вузов. Физика, 9, с.7-16). 
Gretchikhin, L.I., Laptsevich, A.A. \& Kuts, N.G. 2012. Ajerodinamika letatel'nyh apparatov. Minsk, Belarus: Pravo i ekonimka (in Russian). (In the original: Гречихин, Л.И., Лапцевич, А.А., Куць, Н.Г. 2012. Аэродинамика летательных аппаратов. Минск, Беларусь: Право и экономика).

Gretchikhin, L.I., Latushkina, S.D., Komarovskaya, V.M. \& Shmermbekk, Yu. 2015a. The cluster structure of silicon and its surface construction. Strengthening technologies and coatings, 9, pp.5-10 (in Russian) [online]. Available at: https://www.mashin.ru/files/2015/up 0915 01-48 min.pdf [Accessed: 28 April 2021] (In the original: Гречихин, Л.И., Латушкина, С.Д., Комаровская, В.М., Шмермбекк, Ю. 2015а. Кластерная структура кремния и конструкция его поверхности. Упрочняющие технологии и покрытия, 9, c.5-10 [онлайн]. Доступно на: https://www.mashin.ru/files/2015/up_0915_0148_min.pdf [Дата обращения: 28 апреля 2021]).

Gretchikhin, L.I., Latushkina, S.D., Komarovskaya, V.M. \& Shmermbekk, Yu. 2015b. Formation of a close-packed and cluster lattice structure of indium on a silicon surface. Strengthening Technologies and Coatings, 6, pp.3-12 (in Russian) [online]. Available at: http://www.mashin.ru/files/2015/up615_web1.pdf [Accessed: 20 September 2020]. (In the original: Гречихин, Л.И., Латушкина, С.Д., Комаровская, В.М., Шмермбекк, Ю. 2015b. Образование плотноупакованной и кластерной решеточной структуры индия на поверхности кремния. Упрочняющие технологии и покрытия, 6, с.3-12 [онлайн]. Доступно на: http://www.mashin.ru/files/2015/up615_web1.pdf [Дата посещения: 20 сентября 2020 г.]).

Johnson, C.J. \& Keppner, J.P. 1956. Daytime measurement of positive and negative ion composition to $131 \mathrm{~km}$ by rocket-borne spectrometer. Journal of Geophysical Research, 61(3), p.575. Available at: https://doi.org/10.1029/JZ061i003p00575 ).

McMahon, W., Salter, R., Hills, R. \& Delorey, D. 1983. Measured electron contribution to Shuttle plasma environment. In: Shuttle Environment and Operations Meeting, AIAA 1983-2598, Washington, DC, pp.52-58, October 31 November 02. Available at: https://doi.org/10.2514/6.1983-2598.

Papadopoulos, K. 1983. The space shuttle environment as evidence of critical ionization phenomena. In: Symposium Active Experiments in Space, Alpbach, Austria, pp.227-244, May 24-28.

Prince, R.H. 1985. On spacecraft-induced optical emission: a proposed second surface luminescent continuum component. Geophysical Research Letters, 12(7), pp.453-456. Available at: https://doi.org/10.1029/GL012i007p00453.

Shmermbekk, Yu., Migas, D.B., Gutkovsky, A.I. \& Grechikhin, L.I. 2020. Emission portrait of surface of reinforcing structural material. Strengthening technologies and coatings, 16(3), pp.136-143 [online]. Available at: https://www.elibrary.ru/item.asp?id=42573978 [Accessed: 28 April 2021]. 
Zeldovich, Y.B. \& Raizer, Y.P. 1966. Fizika udarnyh voln $i$ vysokotemperaturnyh gidrodinamicheskih javlenij. Moscow: Nauka (in Russian) (In the original: Зельдович, Я.Б., Райзер, Ю.П. 1966. Физика ударных волн и высокотемпературных гидродинамических явлений. Москва: «Наука»)

ПОЛОЖИТЕЛЬНАЯ И ОТРИЦАТЕЛЬНАЯ РОЛЬ ОТРИЦАТЕЛЬНЫХ ИОНОВ В ОСВОЕНИИ КОСМОСА

Леонид И. Гречихин

Белорусская государственная академия связи,

Минск, Республика Беларусь

РУБРИКА ГРНТИ: 55.00.00 МАШИНОСТРОЕНИЕ:

55.49.03 Аэродинамика ракет и космических аппаратов

ВИД СТАТЬИ: оригинальная научная статья

Резюме:

Ведение/цель: При спуске с орбиты полета космических аппаратов c первой и второй космических скоростях без теплозащиты с дюралюминиевой конструкцией на высотах полета от 80 км до 40 км получены данные по увеличению плотности, давления и температуры за фрронтом ударной волны, а также отхода ударной волны от поверхности спускаемого аппарата.

Методы: Через каждые 10 км произведены расчеты потоков энергии на поверхности летательного аппарата при конвективном и лучистом теплообмене, а также при ударном воздействии электронами, которые получены при ионизации отрицательных ионов.

Результаты: При первой космической скорости наибольший поток энергии реализуется при воздействии электронного потока, а при второй космической скорости - лучистый теплообмен. В ударно сжатом газе на всех рассмотренных высотах полета давление повышается меновенно до значения $10^{9} \div 10^{11}$ Па, что приводит к последовательному взрыву с нарастающей мощностью и при этом возникают ударные волны в окружающей атмосфере и волны сжатия во всей конструкции летательного аппарата. Последний самый мощный взрыв возникает на высоте 40 км.

Вывод: Спускаемый аппарат разрушается на отдельные мелкие части вплоть до мелких пылинок.

Ключевые слова: отрицательные ионы, космический аппарат, электризация, конвективный теплообмен, лучистый теплообмен, явление ионизации, ударные волны, взрыв. 


\section{ПОЗИТИВНА И НЕГАТИВНА УЛОГА НЕГАТИВНИХ ЈОНА У СВЕМИРСКИМ ИСТРАЖИВАЊИМА}

Леонид И. Гречихин

Белоруска државна академија за комуникације, Минск, Република Белорусија

ОБЛАСТ: машинство

ВРСТА ЧЛАНКА: оригинални научни рад

Сажетак:

Увод/циљ: За свемирску летелицу од дуралуминијума без заштитне превлаке отпорне на топлоту, која се спушта из орбиталне путање првом и другом космичком брзином, на висини од 80 до 40 км, добијени су подаци о повећању густине, притиска и температуре иза ударног таласа, као и о одбијању ударног таласа од површине свемирске летелице на силазној трајекторији.

Методе: Израчунате су вредности фрлукса енергије ка површини летелице на сваких 10 км, за пренос топлоте конвекцијом и радијацијом, као и за утицај електрона насталих јонизацијом негативних јона.

Резултати: При првој космичкој брзини највећи фрлукс енергије настаје под утицајем фрлукса електрона, а при другој космичкој брзини долази до преноса топлоте радијацијом. У гасу компресованом услед удара, на свим разматраним висинама долази до тренутног пораста притиска до вредности $109 \div 1011$ $\mathrm{Pa}$, што проузрокује ланчане експлозије све веће јачине, као и ударне таласе у околној атмосфери праћене компресивним таласима у целокупној структури летелище. До последње, најснажније експлозије долази на висини од око 40 км.

Закључак: Свемирска летелица се при слетању распада на делове величине честица праха.

Кључне речи: негативни јони, свемирска летелица, напајање, пренос топлоте конвекцијом, пренос топлоте радијацијом, јонизација, ударни таласи, експлозија.

Paper received on / Дата получения работы / Датум пријема чланка: 01.05.2021.

Manuscript corrections submitted on / Дата получения исправленной версии работы / Датум достављања исправки рукописа: 22.06.2021.

Paper accepted for publishingon / Дата окончательного согласования работы / Датум коначног прихватања чланка за објављивање: 24.06.2021. 
(C) 2021 The Author. Published by Vojnotehnički glasnik / Military Technical Courier (www.vtg.mod.gov.rs, втг.мо.упр.срб). This article is an open access article distributed under the terms and conditions of the Creative Commons Attribution license (http://creativecommons.org/licenses/by/3.0/rs/).

(C) 2021 Автор. Опубликовано в «Военно-техническийвестник / Vojnotehničkiglasnik / Military Technical Courier» (www.vtg.mod.gov.rs, втг.мо.упр.срб). Данная статья в открытом доступе и распространяется в соответствии с лицензией «Creative Commons» (http://creativecommons.org/licenses/by/3.0/rs/).

(C) 2021 Аутор. Објавио Војнотехнички гласник / Vojnotehničkiglasnik / MilitaryTechnical Courier (www.vtg.mod.gov.rs, втг.мо.упр.срб). Ово је чланак отвореног приступа и дистрибуира се у складу са Creative Commons лиценцом (http://creativecommons.org/licenses/by/3.0/rs/). 